\title{
Kinerja pustakawan perpustakaan perguruan tinggi islam di Provinsi Bengkulu
}

\author{
Rhoni Rodin \\ Institut Agama Islam Negeri (IAIN) Curup \\ Jl. Dr. AK Gani No. 01, Curup Utara, Rejang Lebong, Bengkulu 39119 \\ Email: rhoni.rodin@iaincurup.ac.id
}

Received: Agustus 2018; Accepted: December 2018; Published: December 2018

\begin{abstract}
In the present era of digital information, academic library professionals are required to perform creatively and innovatively. The purpose of this study was to explore and analyze the performance of academic librarians in fostering creativity and innovation in the digital era. This study used the descriptive qualitative method. Data were obtained through interviews and documentation, while the data analysis was conducted using the qualitative inductive approach. The results showed that university librarians carried some performances in fostering creativity and innovation in the present digital era. First, librarians carried out application-based library automation that was carried out to facilitate library services. Second, librarians created a library website. This website was needed to strengthen the position of the library in the digital era. Third, librarians made the library journal as a place to express their thoughts in the field of libraries and librarianship and even created an Online Journal System (OJS). Fourth, some librarians were able to show their existence by becoming resource persons or presenters in scientific activities in the field of libraries and librarianship. Fifth, librarians were able to implement e-libraries in both e-books and e-journals. This e-library would undoubtedly make it user easier for the user to access information because it was not limited to space and time. In conclusion, the digital era facilitates easy access and use of digital-based information. The librarian's creativity and innovation in this present digital era are needed to improve the librarian performance.
\end{abstract}

Keywords: Performanc; University librarian; Creativity; Innovation; Digital era

\begin{abstract}
Abstrak
Di era perkembangan informasi digital, perpustakaan perguruan tinggi professional harus menunjukkan kinerja yang kreatif dan inovatif. Tujuan dari penelitian ini adalah untuk mengeksplorasi dan menganalisis bagaimana kinerja pustakawan perguruan tinggi dalam menumbuhkan kreativitas dan inovasi di era digital. Jenis penelitian ini adalah deskriptif kualitatif. Data diperoleh melalui wawancara dan dokumentasi. Sedangkan analisis data bersifat kualitatif induktif. Hasilnya menunjukkan bahwa ada beberapa kinerja pustakawan perguruan tinggi dalam menumbuhkan kreativitas dan inovasi di era digital seperti sekarang ini. Pertama, para pustakawan telah melakukan otomasi perpustakaan berbasis aplikasi, hal ini dilakukan dalam rangka memudahkan layanan perpustakaan. Kedua, pustakawan telah membuat website perpustakaan. Website ini diperlukan dalam rangka memperkuat posisi perpustakaan di era digital seperti sekarang ini. Ketiga, pustakawan telah membuat jurnal perpustakaan sebagai wadah untuk menuangkan pemikiran mereka di bidang perpustakaan dan kepustakawanan, bahkan telah membuat Online Journal System (OJS). Keempat, ada beberapa pustakawan telah mampu menunjukkan eksistensi dirinya dengan menjadi narasumber atau pemateri pada kegiatan ilmiah di bidang perpustakaan dan kepustakawanan. Kelima, pustakawan telah mampu menerapkan e-library baik e-book maupun e-journal. E-library ini tentunya akan membuat pemustaka lebih mudah dalam mengakses informasi, karena tidak terbatas ruang dan waktu. Simpulan penelitian ini, era digital membuat pustakawan lebih mudah mengakses informasi berbasis digital. Kreativitas dan inovasi pustakawan di era digital seperti sekarang ini sangat dibutuhkan dalam rangka meningkatkan kinerja pustakawan.
\end{abstract}

Kata Kunci: Kinerja; Pustakawan perguruan tinggi; Kreativitas; Inovasi; Era Digital 


\section{PENDAHULUAN}

Perpustakaan

mengalami

perkembangan pesat dalam dunia digital. Pustakawan melalui dunia digital dapat mempermudah pemberian pelayanan perpustakaan pada pemustaka. Priyanto (2017) dalam Rodin (2017) menjelaskan bahwa "Pustakawan harus siap menghadapi era digital sehingga pustakawan harus mengoptimalkan beberapa kemampuan, di antaranya menulis abstrak, keywords, daftar pustaka, sitasi dan lain-lain".

Selain itu, pustakawan pun harus memiliki kemampuan dalam menggunakan beberapa aplikasi atau perangkat digital dalam pengembangan perpustakaan yakni, "NVIVO, SPSS, SEM, dan optimalisasi kemampuan dalam hal infografis, data, informasi dan knowledge management" (Rodin, 2017). Pustakawan harus memiliki kemampuan alam knowledge management agar bisa memanfaatkan kekayaan perpustakaan bagi pemustaka

Priyanto (2017) dalam Rodin (2017), menambahkan yakni,

"Langkah yang harus dilakukan pustakawan saat ini adalah mengembangkan public knowledge", pustakawan harus mampu mengembangkan pengetahuan lalu melakukan mobilisasi pengetahuan", artinya memindahkan pengetahuan ke layanan aktif untuk kebaikan bersama seluas mungkin. Istilah yang luas dan mencakup produk, proses dan hubungan antara pencipta pengetahuan, pengguna, dan mediator (individu atau organisasi perantara yang mendukung percaloan pengetahuan). Kemudian pustakawan perlu melakukan interaksi melalui dunia nyata dan maya".

Pustakawan perguran tinggi memiliki rutinitas pekerjaan mulai dari pengadaan koleksi, pengolahan koleksi, sampai dengan memberikan layanan kepada pemustaka. Mereka harus memperlihatkan kualitas profesi pustakawan atau memberikan citra yang positif bagi pemustaka yang ada di perguruan tinggi, yaitu pada mahasiswa dan dosen sebagai peneliti.

Rudianto (2015) dalam Rodin (2017) mengatakan bahwa seorang pustakawan harus memiliki kompetensi dasar, di antaranya, "Pustakawan harus selalu ingin terdepan (cepat dan mudah menyiasati perubahan), harus merasa nyaman dengan media online, harus menguasai skill communication (kemampuan bahasa); dan pustakawan juga harus memiliki sikap dan jiwa inovatif dan kreatif". Dalam penggunaan media online sendiri, pustakawan harus merasa nyaman yakni memiliki pengetahuan dan dapat mengoperasikan teknologi informasi.

Di perpustakaan perguruan tinggi, pustakawan harus belajar dan dapat bekerja sama melakukan penelitian lalu menuliskannya. Rudianto (2015) dalam Rodin (2017) menyatakan bahwa, "Seorang pustakawan sejatinya harus mempunyai peran sebagai mitra peneliti dan mitra akademik". Sumber-sumber informasi yang berkualitas dapat termanfaatkan dengan baik apabila telah terbangun kolaborasi antara pustakawan dengan peneliti.

Pustakawan dapat mengambil peran dalam penelitian, baik secara langsung maupun tidak langsung. "Pustakawan jangan hanya bergelut dengan masalah teknis layanan tapi harus mulai menguasai 
kompetensi di bidang reference manager, teknik sitasi, plagiarism checker, dan mengetahui informasi tentang aturan penulisan yang berlaku pada suatu lembaga" (Rodin, 2017).

Dalam peran sebagai mitra akademik,

"Pustakawan harus 'menjemput bola' ke fakultas bahkan program studi. Misalnya untuk mitra akademik bagi dosen, maka seorang pustakawan misalnya masuk kelas dan menawarkan diri membantu dosen dalam proses penelusuran informasi (information literacy) sedangkan untuk mahasiswanya, seorang pustakawan bisa membimbing mahasiswa dalam pembuatan tugas akhir (library based learning)" (Rodin, 2017).

Pustakawan harus memiliki inisiatif sendiri dalam menyebarkan informasi perpustakaan pada pemustaka. Maka, pustakawan melalui media digital dapat memanfaatkan fasilitas untuk mempermudah proses penyebaran informasi di perpustakaan dan melakukan promosi mengenai informasi tersebut.

Sulistiorini (2016) dalam Rodin (2017) menyatakan bahwa, "Pustakawan harus berupaya mengembangkan diri untuk menghadapi era digital melalui pendidikan formal dan non formal, seperti mengikuti kegiatan seminar, workshop, kursus bahasa Inggris, dan pelatihanpelatihan tentang ilmu perpustakaan dan kepustakawanan maupun teknologi informasi dan komunikasi". Pustakawan harus meningkatkan keahlian dalam pengoperasian media digital untuk menunjang pelayanan perpustakaan.

Pustakawan yang diteliti ialah pustakawan di perpustakaan perguruan tinggi Provinsi Bengkulu, yakni pustakawan dari Institut Islam Negeri (IAIN) Bengkulu, Sekolah Tinggi Agama Islam Neger (STAIN) Curup dan Universitas Muhammadiyah Bengkulu (UMB). Penulis berfokus meneliti tentang kinerja pustakawan perpustakaan perguruan tinggi islam di Provinsi Bengkulu.

Secara umum, yang dimaksud dengan pustakawan perguruan tinggi merupakan para pustakawan yang bekerja di perpustakaan perguruan tinggi. Tanggung jawab atau peran utama pustakawan perguruan tinggi adalah mendukung terselenggaranya berbagai kegiatan akademik perguruan tinggi. Dalam konteks Indonesia, kegiatan akademik tersebut tercantum dalam program Tri Dharma perguruan tinggi yaitu mencakup kegiatan pendidikan dan pengajaran, penelitian, dan pengabdian masyarakat. Oleh karena itu, pustakawan di lingkungan perguruan tinggi harus mampu bekerja sama dengan civitas akademika seperti dosen, mahasiswa, dan staf universitas lainnya demi tercapainya tujuan pergruruan tinggi yang bersangkutan.

Andayani (2016) menjelaskan bahwa, "Perpustakaan memiliki peran yang strategis dalam penyelanggaraan program Tri Dharma perguruan tinggi, khusus dalam kegiatan riset. Selain menyediakan sumber-sumber yang diperlukan untuk kegiatan riset, perpustakaan melalui pustakawan perguruan tinggi juga berperan dalam memberikan layanan dan edukasi tentang riset. Pustakawan perguruan tinggi dapat menyediakan layanan konsultasi riset, dan menyelenggarakan pengajaran kemampuan riset 
(research skill) melalui program pendidikan literasi informasi bagi para sivitas akademika".

Para dosen di perguruan tinggi dituntut untuk produktif dalam kegiatan penelitian. Maka, hal ini menjadi peluang bagi pustakawan untuk membantu para dosen dalam mencari informasi mengenai data penelitian dan menuangkan hasil riset tersebut. Selain itu, pustakawan perguruan tinggi dapat berkoordinasi dengan staf akademik untuk memastikan apakah para mahasiswa dan peneliti memiliki materi yang mereka butuhkan. Pustakawan perguruan tinggi akan mengajarkan tentang research skill, yakni pustakawan membantu mahasiswa dan peneliti dalam melakukan pencarian literatur terhadap informasi yang mereka butuhkan.

Dengan demikian, pustakawan perguruan tinggi harus memiliki pengetahuan dalam melakukan manajemen lini staf, yakni antara tim asisten perpustakaan, pustakawan akademik senior dan tim pustakawan. Selain itu, pustakawan perguruan tinggi mungkin juga memiliki jabatan sebagai pustakawan, pustakawan penghubung, penasihat informasi atau pustakawan pendukung pembelajaran.

Sejarah membuktikan bahwa manusia adalah makhluk yang selalu dapat beradaptasi dengan kondisi lingkungan seperti apa pun. Manusia selalu mampu berinovasi sehingga bisa mendapatkan temuan baru yang memberi manfaat bagi kehidupannya. Era ledakan informasi dimulai sejak ditemukannya mesin cetak oleh Guttenberg pada tahun 1440, di mana hal tersebut membuat penyebaran informasi menjadi lebih masif dan tentu saja meningkat secara kuantitas eksemplar. Saat ini, di era internet dan era digital mulai beredar, informasi menjadi begitu mudahnya tersebar dan membawa manusia ke titik yang lebih tinggi dalam ledakan informasi. Menyikapi kemajuan teknologi informasi di era digital seperti sekarang ini, pertanyaannya inovasi apa yang bisa dilakukan oleh pustakawan perguruan tinggi, khususnya dalam memenuhi kebutuhan informasi civitas akademika?

Berdasarkan penelitian Kasperek, Johnson, Fotta, and Craig (2006) dalam Alsop and Bordonaro (2007) menggambarkan partisipasi dan peran pustakawan di kegiatan akademik. Pustakawan misalnya, "Melaporkan dampak yang dirasakan pustakawan yang terlibat dalam produksi teater dan aktivitas orkestra terhadap hubungan mahasiswa dengan perpustakaan" (Alsop \& Bordonaro, 2007).

Pustakawan perguruan tinggi pun melakukan butir-butir kegiatan pustakawan sesuai yang tertuang dalam Peraturan Menteri Pendayagunaan Aparatur Negara \& Reformasi Birokrasi Republik Indonesia nomor 09 tahun 2014 tentang jabatan fungsional pustakawan dan angka kreditnya. Pustakawan berdasarkan tugas pokok dan fungsinya, melaksanakan kegiatan kepustakawanan yang meliputi, "Pengelolaan perpustakaan, pelayanan perpustakaan, dan pengembangan sistem kepustakawanan (Menteri Pendayagunaan Aparatur Negara dan Reformasi Birokrasi Republik Indonesia, 2014).

Pustakawan selain melaksanakan kegiatan rutin perpustakaan, dituntut juga melaksanakan kegiatan dalam pengembangan keahlian pustakawannya. Rice-Lively and Racine (2007) dalam Rodin (2017), menyatakan bahwa, 
“Pustakawan perguruan tinggi dalam beberapa kurun waktu terakhir ini telah mengalami perubahan yang sangat luar biasa seiring dengan kemajuan teknologi informasi. Pustakawan harus mampu menempatkan diri dalam sebuah sistem sosial khusus untuk memahami dan merespon secara cepat dan tepat dalam sistem tersebut (dalam hal ini masyarakat kampus). Pustakawan harus beradaptasi dan menyesuaikan perannya dalam memberikan layanan kepada pemustaka. Dalam hal ini pustakawan sering disebut sebagai "interactors".

Berdasarkan hal ini, pustakawan perguruan tinggi perlu melakukan transformasi perpustakaan yakni, "Pustakawan perguruan tinggi sudah mulai diproyeksikan untuk layanan perpustakaan bagi mahasiswa yang kesulitan dalam menyelesaikan studinya melalui peran pustakawan sebagai "book keeper" menjadi "network navigator", sehingga menjadi istilah "informational professional" (Rodin, 2017).

Adanya kehadiran teknologi informasi ini di perpustakaan memberikan beberapa dampak bagi pustakawan. Rodin (2014) menyebutkan diantaranya, 1) Pustakawan perlu memiliki pengetahuan tentang teknologi dan komunikasi informasi., 2) Pustakawan perlu nemiliki keterampilan teknologi informasi, 3) Pustakawan memerlukan alat teknologi dan komunikasi informasi, dalam berbagai program, 4) Pustakawan perlu belajar terus menerus dalam konteks teknologi dan komunikasi informasi yang terus menerus berubah, dan 5) Lembaga pendidikan pustakawan harus mengintegrasikan teknologi informasi ke dalam kurikulum dan pelatihan guna menghasilkan lulusan yang mampu menyesuaikan dengan lingkungan yang selalu berubah.

Berdasarkan pemaparan di atas, Cangara (2015) menyatakan bahwa,

"Sudah menjadi suatu harga mati bagi pustakawan apabila tidak ingin ditinggal pemustakanya untuk selalu memperbaharui dirinya melalui keahalian pemrograman dasar dan manajemen website agar bisa selalu memberikan pelayanan perpustakaan secara up to date. Pustakawan yang berkutat dengan alasan klasik dan menjauhi pola kerja perpustakaan digital akan dengan sendirinya semakin tergerus dengan perkembangan jaman. Pada hakikatnya perpustakaan dan pustakawan tidak berubah, yakni sebagai penyedia informasi. Hanya saja, apakah pola layananannya mau berubah mengikuti generasi digital native atau tidak itu yang menjadi persoalan utama".

Pustakawan menyikapi kemajuan teknologi informasi dan berkaitan dengan fungsi pustakawan perguruan tinggi maka diperlukan adanya peran sebagai translater, penunjuk, dan tenaga pengajar bagi pemustaka. Tenaga pengajar dalam konteks information literacy sangat diperlukan pada tataran perguruan tinggi. Profesi pustakawan yang berhubungan langsung dengan masalah knowledge management mempunyai peran yang sangat urgen. Peran ini tentunya menempatkan pustakawan memegang peran penting dalam preservasi pengetahuan.

Rodin (2017) menambahkan bahwa, 
“Lingkungan perguruan tinggi merupakan lingkungan akademik yang selalu mengapresiasi sikap kritis dan mempunyai ekspektasi yang tinggi terhadap kualitas layanan perpustakaan yang diberikan oleh para pustakawan. Sikap ini tentunya punya kecenderungan membuat para pustakawan menjadi rentan terhadap kritik dan objek penilaian dalam mengevaluasi kualitas layanan akademik di suatu perguruan tinggi. Problem tersebut menjadi semakin rumit tatkala gap antara harapan pemustaka dan realitas kualitas layanan pustakawan yang terlalu tinggi".

Kadangkala, pustakawan akan menghadapi situasi yang bertentangan dengan profesi kepustakawanan di perpustakaan. Dalam menghadapi hal ini, peran pustakawan sebagai penyaring dan penyebar informasi diperlukan agar dapat memberikan kenyamanan bagi pemustaka.

Berangkat dari kondisi di atas, Naibaho (2015) dalam Rodin (2017) memberikan beberapa saran bagi pemustaka, yakni pustakawan harus memberikan pelayanan yang akurat karena pemustaka mengharapkan layanan yang cepat dan tepat yang diberikan. Lalu pustakawan harus memberikan ketepatan waktu dalam memberikan pelayanan, maka kedisiplinan pustakawan sangat dituntut oleh pemustaka. Pustakawan pun harus memberikan kemudahan dalam mendapatkan layanan, pustawakan jangan mempersulit para pemustaka dalam memperoleh informasi. Farhanah and Zulaikha (2016) menambahkan bahwa pustakawan yang mengelola kecerdasan emosi dengan baik maka akan melayani pemustaka dengan kualitas yang baik.

Selain itu, pustakawan harus bersikap sopan dan ramah ke pemustaka. Pustakawan harus memiliki etika dalam pemberian pelayanan kepada pemustaka. Selain itu, agar pemustaka merasa nyaman dalam pelayanan perpustakaan, maka harus diperhatikan letak perpustakaan, kondisi ruangan, dan kemudahan dalam memperoleh informasi. Pustakawan pun harus menerima sentuhan pribadi, berupa penerimaan penghargaan secara personal, dan kemudahan dalam proses pekerjaan di perpustakaan.

Selain harapan-harapan di atas, para pemustaka perguruan tinggi juga menginginkan beberapa program perpustakaan yang bersentuhan langsung dengan kegiatan akademik, misalnya program literasi informasi. Program ini tentunya akan memberikan manfaat bagi pemustaka di perguruan tinggi, karena dapat berinteraksi langsung dan merasakan peran pustakawan dalam proses pendidikan dan pengajaran (perkuliahan) di perguruan tinggi. Pustakawan dan perpustakaan perguruan tinggi pun harus memiliki mempunyai program-program yang inovatif dan kreatif dalam rangka pengembangan masyarakat ilmiah kampus sehingga bisa tercipta iklim akademik dan ilmiah dari perpustakaan.

Eksistensi dan berkembangnya perpustakaan bergantung pada kualitas sumber daya manusianya, sehingga ada istilah dalam dunia perpustakaan dan kepustakawanan yaitu library is librarian. Oleh karena itu, pustakawan harus menyalurkan kreativitasnya, terutama di era teknologi dan digital seperti sekarang ini. Pustakawan dituntut untuk kreatif dan inovatif dalam berbagai kegiataan dalam 
bidang perpustakaan dan kepustakawanan. Pustakawan sebagai penjaga peradaban informasi, mediator, fasilitator, harus mampu meningkatkan kreativitasnya dan membangun inovasi. Bukan waktunya lagi pustakawan hanya sebagai pelayan perpustakaan atau menunggu pemustaka yang datang berkunjung ke perpustakaan.

Kemajuan teknologi informasi telah merubah mindset dan peran para pustakawan. Pada era sekarang ini peran pustakawan meliputi aspek hard skill dan soft skill. Hard skill menurut Rodin (2017), ialah "Kemampuan menguasai hal-hal yang bersifat teknis dan rinci bidang kepustakawanan, sedangkan soft skill berhubungan dengan kemampuan berpikir strategis sebagai perumus kebijakan, punya visi ke depan (forward looking), dan mampu membuat perencanaan strategis, kemampuan manajerial, kemampuan komunikasi publik, dan lainnya yang berkaitan dengan perpustakaan".

Lalu Rodin (2017) menambahkan bahwa, "Tujuan dari penguasaan multi task tersebut adalah agar pustakawan mempunyai kompetensi. Kompetensi tersebut akan mengangkat dan memberikan citra positif serta meningkatkan kinerja pustakawan".

Menurut Rodin (2017), "Selama ini stereotipe yang melekat pada pustakawan sungguh sangat ironis, misalnya bekerja di perpustakaan dianggap sebagai tempat buangan. Di sisi lain, memang ada image dan anggapan masyarakat yang berkembang selama ini bahwa pustakawan itu kinerjanya hanya sebatas pelayanan dan tidak ramah pada pemustaka".

Di era digital, pustakawan harus kreatif dalam memberikan pelayanan perpustakaan. Pustakawan harus memiliki inovasi di setiap produk perpustakaan. Pendit (2007) dalam Rodin (2017) memberikan kriteria yang harus dimiliki pustakwan dalam era digital, diantaranya, "Kemampuan menggunakan alat-alat teknologi informasi, memahami dan menilai berbagai sumber-sumber informasi, memahami bagaimana masyarakat menghasilkan informasi, kemampuan dalam melakukan riset atau penelitian, kemampuan mempublikasikan informasi dan ide ilmiah kepada masyarakat dengan menggunakan teknologi informasi, kemampuan untuk beradaptasi terhadap perkembangan teknologi secara kontinyu dan mampu mengevaluasi penggunaan teknologi informasi dalam kegiatan ilmiah.

Selain itu, pustakawan pun harus memiliki sikap daya juang (survival skills). Kritsina (2016) dalam Rodin (2017) memberikan gambar mengenai survival skills yakni,

"pustakawan harus memiliki kemampuan dalam scanning terhadap lingkungan dan membuat keputusan yang tepat, menganalisa secara kritis pada lingkungan yang profesionalnya, time management manage change, work collaboratively, membangun kerjasama dalam suatu organisasi, belajar secara mandiri, think creatively, dna dapat melakukan evaluasi diri".

Pustakawan yang memiliki keahlian ini akan memberi peluang untuk mampu melakukan kreativitas dan inovasi. Pustakawan melakukan suatu hal yang tak pernah terpikir oleh orang lain sehingga mampu memberi kepuasaan kepada pemustaka serta mengangkat citra pustakawan di mata masyarakat. 
Solso, Maclin, and Maclin (2008) memberi definisi kreativitas sebagai, "Suatu aktivitas kognitif yang menghasilkan suatu pandangan yang baru mengenai suatu bentuk permasalahan dan tidak dibatasi pada hasil yang pragmatis (selalu dipandang menurut penggunaannya)". Dalam konteks ini, seorang kreativitor sesungguhnya tidak harus menciptakan hal-hal yang baru, tetapi mengkombinasikan dari hal-hal yang sudah ada sebelumnya sedangkan yang dimaksud dengan data, informasi, atau unsur-unsur yang ada, dalam arti sudah ada atau sudah dikenal sebelumnya, adalah semua pengalaman yang telah diperoleh seorang selama hidupnya termasuk segala pengetahuan yang pernah diperolehnya. Dengan demikian dapat dirumuskan bahwa, kreativitas merupakan kemampuan yang menunjukkan kelancaran, fleksibelitas dan berpikir orisinil, serta kemampuan untuk mengelaborasi suatu gagasan. Ciri-ciri kreativitas seperti ini merupakan ciri-ciri yang berkaitan dengan kemampuan berpikir seseorang dengan kemampuan berpikir kreatif sehingga semakin kreatif seseorang maka ciri-ciri tersebut semakin dimilikinya. Tetapi ciri-ciri tersebut belum menjamin perwujudan kreativitas seseorang karena seseorang harus memiliki sikap dan perasaan untuk memotivasi kreativitas seseorang.

Dalam konteks dunia kepustakawanan, kreativitias tidak hanya ditunjukkan dengan memberikan pengetahuan konseptual dan teoritis mengenai berbagai masalah informasi dan masalah sosial yang terkait dengan kemampuan analisis pustakawan dalam menciptakan produk baru di perpustakaan. Hanya dengan berpikir secara teoritis yang berjenjang serta visioner akan dapat meningkatkan kreativitas pustakawan. Pustakawan membutuhkan suatu sarana dan wadah untuk mengkaji masalah-masalah yang berkaitan dengan kreativitas pustakawan di era digital melalui berbagai kegiatankegiatan ilmiah seperti penelitian, pengkajian, seminar dan sebagainya, yang dapat dipertanggungawabkan secara ilmiah.

Berkaitan dengan kreativitas ini, Munandar (2009) dalam Rodin (2017) mengkategorikan kreativitas menjadi 4 (empat) jenis, diantarnya, "Pribadi kreatif, proses kreatif, dukungan lingkungan, dan hasil kreatif". Dalam pribadi kreatif, pustakawan menjadi penggerak sekaligus landasan bagi tumbuhnya kegiatan kreatif. Di proses kreatif, pustakawan selalu menghasilkan ide-ide kreatif dari adaptasi lingkungan dan suasana kerjanya. Lalu melalui dukungan lingkungan tersebut menjadikan pustakawan menghasilkan variasi/ aneka ragam aktivitas kreatif. Terakhir, sesuai hasil kreatif ini, pustakawan dapat memproduksi produk yang untuk dimanfaatkan pemustaka.

Munandar (2009) dalam Rodin (2017) menambahkan beberapa ciri individu yang memiliki potensi kreatif, yakni, "Rasa ingin tahunya tinggi artinya seseorang yang kreatif tentunya mempunya hasrat ingin tahunya sangat tinggi dan besar, bersikap terbuka terhadap pengalaman baru, panjang akalberpandangan luas dan tidak sempit memandang suatu persoalan, keinginan menemukan dan meneliti suatu persoalan yang dihadapinya, memiliki kecenderungan senang menghadapi tugas yang berat dan sulit, menyukai tantangan dan tugas yang bisa membuatnya berpikir secara kreatif dan inovatif, lebih suka mencari jawaban yang luas dan 
memuaskan, mempunyai dedikasi yang tinggi dan atraktif dalam menjalankan tugas, memiliki cara berpikir yang tidak kaku.

Selain itu, seseorang tersebut dapat tanggap terhadap pertanyaan yang diajukan dan punya kecenderungan memberi jawaban lebih variatif, mampu membuat analisis dan sintesis, mempunyai semangat bertanya serta meneliti, memiliki daya abstraksi yang mumpuni, dan mempunyai kemampuan membaca yang".

Pustakawan yang kreatif mampu berpikir positif dan kreatif dalam menjalani tugas pokok dan fungsinya di dunia kepustakawanan. Hal ini diharapkan pustakawan mampu beradaptasi dan terus mengembangkan diri di perpustakaan menggunakan media digital.

Pustakawan yang profesional dan kreatif akan membawa dampak positif bagi reputasi pustakawan tersebut di masyarakat. Restiani (2015) dalam Rodin (2017) menyebutkan ada 12 cara untuk membangun reputasi pustakawan. Pertama, menulis artikel dalam majalah, jurnal, atau surat kabar baik lokal, nasional maupun internasional secara online. Kedua, membaca. Ketiga, melakukan pembaharuan informasi dan pengetahuan. Keempat, pustakawan membangun perpustakaan pribadi, untuk memberikan bantuan informasi dan pengetahuan serta pengembangan profesi. Kelima, mengikuti seminar, workshop dan pelatihan. Keenam, berkenalan dengan pakar/praktisi di bidang ilmu perpustakaan. Ketujuh, pustakawan menjaga penampilan diri. Kedelapan, mengenali dunia profesi kepustakawanan. Kesembilan, produktif. Kesepuluh, mengembangkan keterampilan. Kesebelas, melihat gambaran besar dan mimpi besar. Keduabelas, memperluas jaringan.

Berdasarkan uraian diatas, dapat dipahami bahwa seorang pustakawan dalam meningkatkan kreativitasnya sejatinya terus mengasah kemampuannya dan mengembangkan diri. Seorang pustakawan harus mempunyai rasa percaya diri yang tinggi, harus mempunyai komitmen yang bagus, serta mampu membangun komunikasi dan relasi yang positif dengan professional lain seperti psikolog, programmer, penulis dan sebagainya. Dengan demikian diharapkan lewat hal seperti itu pustakawan termotivasi serta mampu menangkap ideide baru yang bisa diterapkan dalam dunia perpustakaan dan kepustakawanan.

\section{METODE PENELITIAN}

Jenis penelitian ini adalah deskriptif kualitatif. Sugiyono (2010) mengatakan bahwa tujuan dari penelitian kualitatif, "Untuk mendeskripsikan realita empirik di balik fenomena secara mendalam, rinci dan tuntas". Dalam penelitian ini, data diperoleh melalui wawancara kepada para pustakawan sebagai informan, dan studi dokumentasi mengenai informasi yang berkaitan dengan kinerja pustakawan. Analisis data yang dilakukan bersifat induktif kualitatif. Di mana hasil penelitian kualitatif, "Lebih menekankan pada makna dari pada generalisasi" (Sugiyono, 2010). Penulis dapat memperoleh gambaran dari para pustakawan dalam dunia perpustakaan di era digital melalui data yang diperoleh.

\section{HASIL DAN PEMBAHASAN}

Pustakawan perguruan tinggi memainkan peran yang sangat penting dalam kegiatan akademik universitas. Peranan tersebut bisa berupa memberikan 
bimbingan kepada mahasiswa, dosen dan peneliti di layanan referensi, melakukan pelatihan information research skill (IRS) bagi civitas akademika di perpustakaan, dan mengembangkan koleksi perpustakaan. Hal ini menyangkal anggapan sebagian besar orang terhadap pustakawan hanya sebagai penjaga buku.

Peran pustakawan perguruan tinggi adalah berkoordinasi dengan staf akademik untuk memastikan bahwa mahasiswa dan peneliti memiliki materi yang mereka butuhkan sehingga dapat diakases dengan mudah. Pustakawan mengajarkan keterampilan literasi informasi (information research skill) pada mahasiswa dan peneliti agar mereka dapat melakukan pencarian literatur sendiri. Pustakawan akan memastikan bahwa kebutuhan informasi mahasiswa dan civitas akademika dapat terpenuhi sesuai pertanyaan yang diajukan pada pustakawan.

Supriyanto (2012) dalam Rodin (2017) menjelaskan mengenai, "Arah pengembangan pustakawan sesuai tugas pokok dan fungsinya sebagai wujud karakter pustakawan yang dikehendaki. Maka, diperlukan peningkatan profesionalisme dan membangun kreativitas inovatif para pustakawan".

Dalam meningkatkan profesionalisme dan membangun kreativitas inovatif tentunya akan membawa dampak positif bagi reputasi pustakawan. Sesuai 12 cara dalam membangun reputasi pustakawan, pustakawan diharapkan mampu mengaplikasikannya untu membangun kreativitas dan inovasi pustakawan, citra positif dan reputasi pustakawan di tengah masyarakat.

Pustakawan kreatif adalah pustakawan yang bisa membuat ide - ide dan metode yang berfungsi untuk menarik minat masyarakat terhadap berbagai fasilitas bacaan perpustakaan. Sebagaimana kita ketahui bahwa tugas pustakawan tidak hanya sebatas melakukan rutinitas pekerjaan sebagai pustakawan saja, akan tetapi dituntut untuk mampu membuat program serta terobosan yang membuat pemustaka sering mengunjungi perpustakaan dan mencintai perpustakaan.

Selain itu, fasilitas perpustakaan juga harus membuat nyaman pemustaka ketika membaca, memiliki ruang yang memadai, dan pelayanan nyaman sehingga para pemustaka betah berada di perpustakaan. Menindaklanjuti hal ini, maka perpustakaan pun harus dapat bersikap secara profesional dan berkompeten dalam menjawab kebutuhan dan menyediakan koleksi perpustakaan yang lengkap dan sesuai dengan kebutuhan pemustaka.

Pustakawan disebut sebagai orang yang menguasai teori dan praktik di bidang perpustakaan atau ahli perpustakaan. Pustakawan ada juga yang menyebutnya sebagai seorang yang melaksanakan kegiatan kepustakawanan dengan jalan memberikan pelayanan kepada pemustaka sesuai visi misi lembaga induknya melalui pendidikan dan pelatihan. Oleh karena itu, pustakawan harus kreatif menemukan ide-ide dan metode baru dalam rangka menarik minat para pemustaka untuk berkunjung ke perpustakaan. Pustakawan tidak boleh hanya duduk di belakang meja sirkulasi dan menunggu pengunjung datang ke perpustakaan. Pustakawan harus bisa menciptakan metode untuk menjadikan membaca sebagai budaya di tengah masyarakat sehingga ada korelasi positif antara penurunan angka buta aksara dengan gerakan dan budaya membaca. Pustakawan harus inspiratif 
dan tidak hanya mengerjakan rutinitas pekerjaan sebagai pustakawan. Kegiatan inspiratif dan kreatif tersebut bisa berupa sebagai penulis, konsultan perpustakaan dan informasi, analisis informasi bahkan menjadi seorang pengusaha. Pustakawan harus memiliki konsep diri dan mimpi yang harus diaktualisasikan dalam pelayanan di perpustakaan, sehingga kemanfaatannya tidak hanya dibutuhkan oleh pemustaka tetapi juga dapat meningkatkan kesejahteraan bagi pustakawan itu sendiri.

Salah satu narasumber mengatakan bahwa,

"Sebelum kita masuk ke era digital, maka kita harus mempersiapkan SDM yang ada, meningkatkan kompetensi, menyediakan perangkat yang digunakan. Untuk menumbuhkan kreatifitas dan inovasi pustakawan seharusnya berusaha menemukan cara untuk memenuhi harapan pemustaka" (Syahril, wawancara, , January 1, 2018).

Jurnal al-maktabah merupakan salah satu bentuk kreativitas pustakawan IAIN Bengkulu. Para pustakawan dapat termotivasi untuk menulis di jurnal ini.

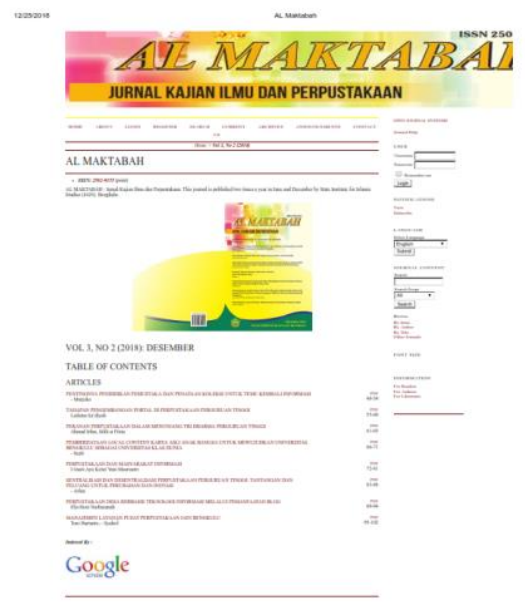

Gambar 1. Tampilan website Jurnal Al-Maktabah Sumber: IAIN Bengkulu, 2018a
Selain itu, narasumber lainnya pun mengungkapkan, "Sebagai pustakawan upaya yang kita lakukan untuk menumbuhkan kreativitas dan inovasi di era digital sekarang antara lain menambah wawasan dan menambah kemampuan/keahlian terkait dengan digitalisasi" (Arlan, wawancara, January 1, 2018). Menambah wawasan dan pengetahuan ini bisa dengan mengikuti kegiatan ilmiah berupa seminar ilmiah, pertemuan ilmiah, diskusi ilmiah, dan pelatihan di bidang kepustakawanan. Juga pustakawan dapat mengikuti atau menjadi pengurus organisasi profesi seperti Ikatan Pustakawan Indonesia (IPI). Organisasi ini merupakan wadah untuk belajar dan pengembangan diri.

Dalam meningkatkan layanan otomasi pusat Perpustakaan IAIN Bengkulu telah berbasis digital. Komputer menjadi salah satu sarana dalam rangka meningkatkan layanan kepada pemustaka. Di sisi lain otomasi perpustakaannya juga telah berbasis SLiMS. Selain daripada itu, Pusat Perpustakaan IAIN Bengkulu juga telah mempunyai website yang dapat dilihat pada gambar di bawah ini.

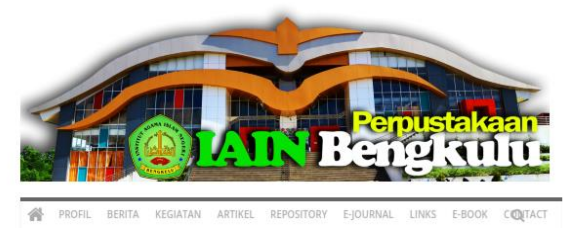

Gambar 2. Tampilan website Perpustakaan IAIN Bengkulu

Sumber: IAIN Bengkulu, 2018b

Produk kreatif merupakan andalan bagi kreativitas pustakawan yang akan dimanfaatkan oleh para pemustaka. Bara (2012) mengungkapkan bahwa, "pustakawan yang ideal memiliki sikap yang commited to learning yaitu berusaha mencari pengetahuan secara terus menerus, mensintesakan segala input, 
menyeimbangkan segala informasi yang terkumpul dan menyelaraskan setiap tindakan."

Hal ini sejalan dengan ada yang diungkapkan Pendit (2007) dalam Rodin (2017), yakni pustakawan harus memiliki keterampilan, "Tool Literacy, kemampuan memahami dan menggunakan alat teknologi informasi, baik secara teoritis maupun praktis, terampil dalam menggunakan perangkat lunak, perangkat keras, multimedia, dan sebagainya".

Lain halnya, di Perpustakaan UMB, pustakawan selalu melakukan pembenahan di segala bidang dalam rangka meningkatkan kualitas pelayanan kepada pemustaka. Pembenahan ini menunjukkan adanya kreativitas dan inovasi para pustakawannya, diantaranya otomasi perpustakaan, e-library, dan mengikuti kegiatan ilmiah.

Otomasi perpustakaan merupakan salah satu sarana untuk memudahkan dan mempercepat layanan kepada pemustaka. Satu narasumber mengatakan,

“Kami pustakawan UMB sekarang selalu berbenah untuk meningkatkan pelayanan ke para pemustaka, untuk sekarang ini kami baru beralih dari perpustakaan yang belum terotomasi menuju perpustakaan yang sudah terotomasi (otomasi perpustakaan) dengan memakai aplikasi SLIMS, sekarang ini kami lagi mempersiapkan E-Library (EJournal, E-Book). Produk kreatif tentunya menjadi andalan bagi aktivitas kreatif yang akan selalu dimanfaatkan oleh para pemustaka" (Susanti, M., wawancara, January 1, 2018).

Hal ini diperkuat Bara (2012) yang mengatakan, "Pustakawan yang ideal memiliki sikap yang commited to learning yaitu berusaha mencari pengetahuan secara terus menerus, mensintesakan segala input, menyeimbangkan segala informasi yang terkumpul dan menyelaraskan setiap tindakan.

Menurutnya, pustakawan harus memiliki kreatifitas untuk mengembangkan perpustakaan agar dapat memenuhi tuntutan era digital. Maka, pustakawan harus mengikuti pendidikan dan pelatihan sebaga sarana untuk menambah wawasan, pengetahuan dan pengalaman pustakawan. Lebih lanjut Epstein (1999) dalam Rodin (2017) menceritakan bahwa, "Sangat penting bagi seseorang yang kreatif untuk memiliki wawasan yang luas. Jangan sungkan untuk mempelajari hal-hal baru yang mungkin tidak berhubungan dengan pekerjaan atau pendidikan".

Selain itu, pustakawan melalui tool Literacy, dapat memahami dan menggunakan alat teknologi informasi speerti, perangkat lunak, perangkat keras, multimedia, dan sebagainya. Salah satunya ialah otomasi perpustakaan berbasis SLiMS (Senayan Library Management System). Perangkat lunak (software) ini merupakan gebrakan yang sangat bagus di Perpustakaan UMB. Beralihnya dari sistem manual ke otomasi merupakan prestasi tersendiri bagi Perpustakaan UMB. Perpustakaan UMB telah memiliki website yang dapat diakses di laman

\section{PUSAT PERPUSTAKAAN UMB}
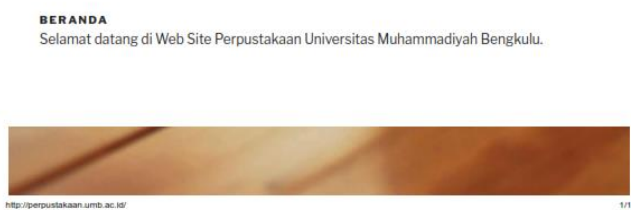

Gambar 3. Tampilan website Perpustakaan UMB Sumber: Universitas Muhammadiyah Bengkulu (UMB), 2018 
Selain itu, perpustakaan ini pun memiliki sistem otomasi untuk pelayanan perpustakaan atau OPAC (online public access catalogue). Berikut tampilan OPAC Perpustakaan UMB d bawah ini.

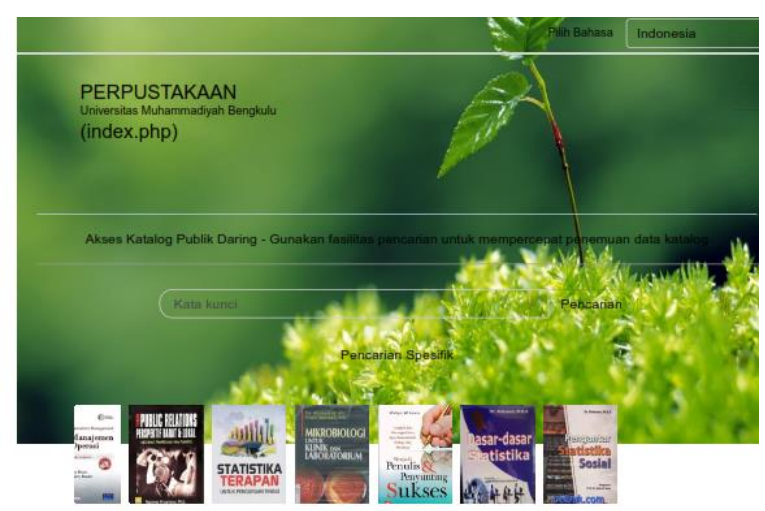

Gambar 4. Tampilan OPAC Pusat Perpustakaan $\mathrm{UMB}$

Sumber: Universitas Muhammadiyah Bengkulu (UMB), 2018a

Perpustakaan UMB yang telah memiliki websiten dan otomasi perpustakaan memperlihatkan bentuk kreativitas pustakawannya. Pustakawan melalui website perpustakaan dapat mengembangkan diri dan mempromosikan perpustakaan sedangkan melalui otomasi perpustakaan, pustakawan belajar bekerja secara cepat dan tepat.

Selain itu, Perpustakaan UMB sedang dirancang menuju e-library. "Kontennya nanti akan berisi e-book dan e-journal. Layanan ini nantinya diharapkan bisa meningkatkan kualitas layanan kepada pemustaka di era digital seperti sekarang ini" (Susanti, M., wawancara, January 1, 2018).

Tak hanya itu, perpustakaan ini pun menggelar kegiatan rutin berupa kegiatan ilmiah. Kegiatan ini merupakan salah satu wadah untuk mengembangkan potensi dan kualitas sumber daya manusia, termasuk dalam hal ini SDM yang ada di perpustakaan. Beberapa kegiatan seminar, pertemuan ilmiah telah diikuti oleh para pustakawan UMB baik yang berskala local maupun nasional.

Sejalan dengan pemaparan di atas, maka ada beberapa kinerja yang telah dihasilkan oleh para pustakawan perguruan tinggi dalam rangka menumbuhkan kreativitas dan inovasi di era digital seperti sekarang ini. Kreativitas dan inovasi merupakan suatu hal yang penting karena kreativitas inovasi merupakan kendaraan bagi pustakawan untuk menjadi pemenang dalam segala bidang, diantaranya otomasi perpustakaan Berbasis SLiMS, penggunaan website perpustakaan, membuat jurnal perpustakaan, dan mengikuti kegiatan ilmiah.

Otomasi Perpustakaan STAIN Curup berbasis SLiMS ini telah lama dilakukan oleh para pustakawannya. Perpustakaan STAIN Curup ini merupakan perpustakaan yang pertama terotomasi berbasis SLiMS di Provinsi Bengkulu. Penggunaan SLiMS ini telah dimulai sejak tahun 2010. Sebelumnya Perpustakaan STAIN Curup menggunakan software yang bernama Simpus.

Selain itu, perpustakaan ini memiliki website perpustakaan merupakan sebagai bentuk proses dan product kreatif dari seseorang yang kreatif. Dan menjadi salah satu bentuk inovasi pustakawan di era digital seperti sekarang ini. Munandar (2002) dalam Rodin (2017), mengategorikan kreativitas menjadi 4 (empat) konsep, diantaranya,

"Pribadi kreatif, merupakan person yang akan menjadi motor penggerak sekaligus pondasi bagi tumbuhnya kegiatan-kegiatan yang kreatif, yang akan menghasilkan lingkungan dan suasana kerja untuk selalu menghasilkan ide-ide 
baru dalam men-support kegiatan kreatif. Dorongan/dukungan lingkungan juga akan memberi pengaruh yang variatif bagi kegiatan kreatif. Kemudian Produk kreatif tentunya akan menjadi andalan bagi kegiatan kreatif untuk selalu diberdayakan oleh para pemustaka".

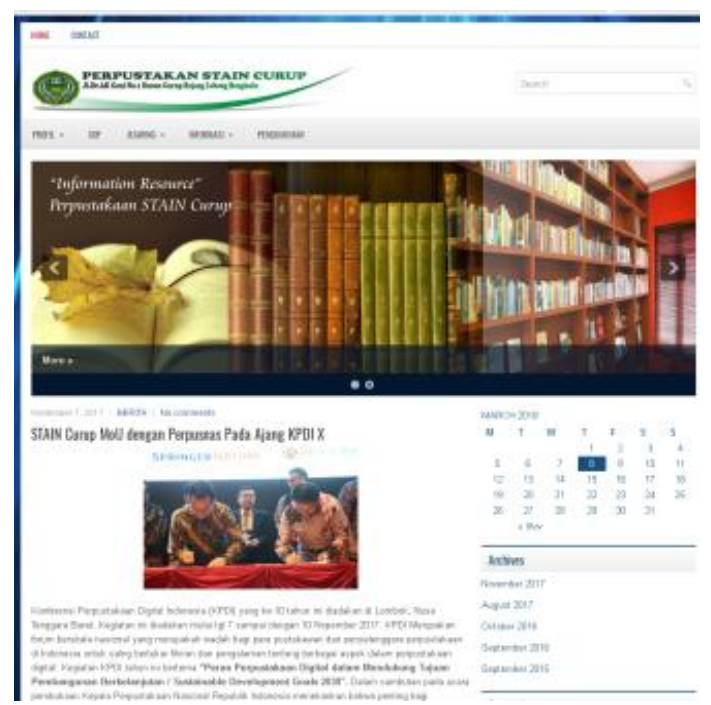

Gambar 5. Tampilan Website Perpustakaan STAIN Curup

Sumber: STAIN Curup Bengkulu, 2018

Selain sistem otomasi perpustakaan dan website, perpustakaan ini pun memiliki jurnal perpustakaan, bernama "Tik Ilmeu". Jurnal ini menjadi wadah bagi para pustakawan untuk mengembangkan kemampuan menulis dan melahirkan pemikiran-pemikiran yang berguna bagi pengembangan dunia kepustakawanan. Jurnal berkala ilmiah yang diterbitkan oleh Perpustakaan STAIN Curup memiliki fokus kajian dalam bidang ilmu perpustakaan dan informasi serta memilki tujuan untuk menjadi wadah dan mensosialisasikan berbagai gagasan inovatif dan kreatifitas Pustakawan dan Peneliti di bidang kepustakawanan. Jurnal ini telah terindek oleh beberapa pengindeksing di antaranya Moraref, Google Scholar, dan lain-lain.

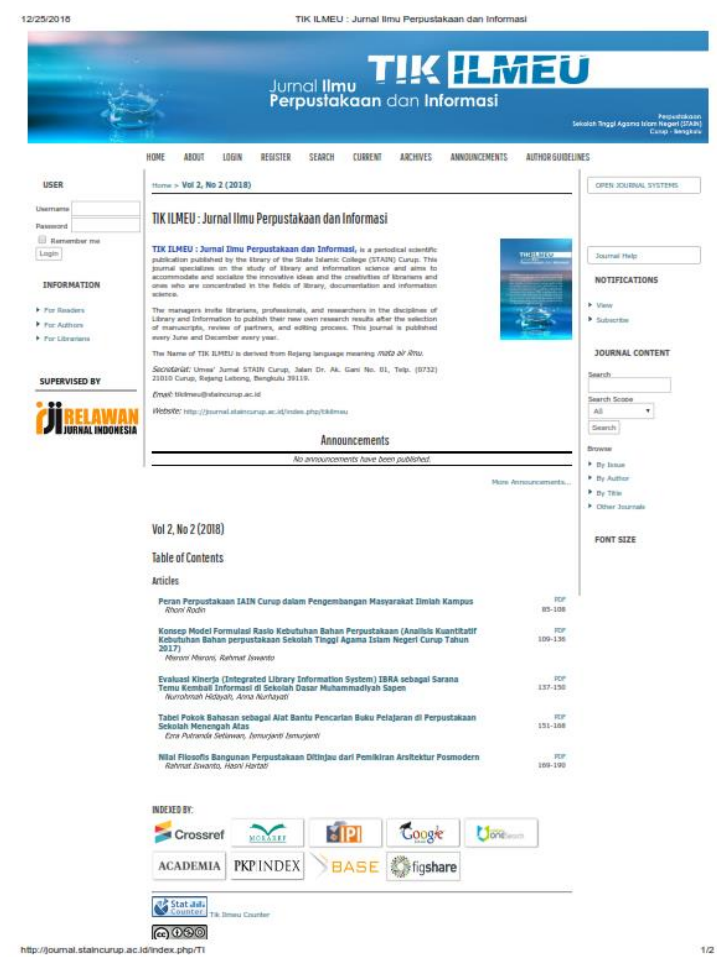

Gambar 6. Tampilan Website Jurnal Tik Ilmeu Sumber: Perpustakaan Sekolah Tinggi Agama Islam Negeri (STAIN) Curup, 2018

Pembentukan jurnal merupakan salah satu proses kreatif yang dilakukan oleh pribadi kreatif tentunya. Pribadi kreatif akan menjadi motor penggerak sekaligus pondasi bagi tumbuhnya kegiatan kreatif. Narasumber mengatakan, "Karena banyaknya uraian pekerjaan dalam jabatan pustakawan maka untuk menyiasatinya adalah dengan membangun personality yang kuat, artinya kita harus bisa menumbuhkan jiwa dan pribadi yang kreatif dalam diri kita sehingga kita mampu melaksanakan tugas secara baik sesuai dengan tupoksi kita" (Wince, E., wawancara, January 1, 2018).

Seorang pustakawan yang memiliki pribadi yang kreatif akan terus menerus memikirkan untuk mewujudkan sesuatu, dan ia tidak pernah akan berhenti sebelum sesuatu itu terwujud. Seorang pustakawan akan melakukan yang terbaik, baginya setiap hari merupakan hari baru yang membawa kesempatan untuk berkreativitas dan berinovasi. Setiap 
pustakawan pasti memiliki hal tersebut yang berbeda-beda. Oleh karena itu, setiap pustakawan harus mulai menggalinya dan menjalani hidupnya dengan penuh semangat.

Pribadi yang kreatif membuat seseorang punya semangat juang (fighting spirit) yang tidak mudah menyerah dan putus asa dalam menghadapi berbagai masalah sesulit apa pun, termasuk di bidang pekerjaan. Masalah justru menjadi pemicu untuk mencari terobosan, maka disinilah pribadi yang kreatif akan memunculkan kreativitas inovatif secara spontan. Tanpa hal ini, seorang pustakawan sulit untuk dapat meraih prestasi gemilang dan cemerlang.

Beberapa pustakawan STAIN Curup telah menjadi narasumber atau pemateri pada beberapa kegiatan ilmiah, baik yang berskala lokal, regional maupun nasional. Termasuk pengembangan SLiMS pada beberapa Perpustakaan di Provinsi Bengkulu yang dilakukan oleh saudara Jurianto, sebagai pengembangnya. Di sisi lain, ada juga pustakawannya yang telah menghasilkan tulisan baik berupa opini, artikel maupun buku, baik yang berskala lokal maupun nasional.

Dalam rangka meningkatkan kualitas dan wawasan, maka beberapa pustakawan STAIN Curup mengikuti kegiatan ilmiah, baik yang berskala regional maupun nasional, bahkan ada satu orang pustakawan telah mengikuti kegiatan yang berskala internasional, yaitu kegiatan DELSMA (Development System of Library Mangement) yang diadakan oleh Direktorat Pendidikan Tinggi Keagamaan Islam Kementerian Agama. Kegiatan DELSMA ini merupakan salah satu sarana untuk mengembangkan kualitas dan menambah wawasan di bidang perpustakaan dan kepustakawanan. Penulis sendiri merupakan salah satu pesertanya yang mewakili dari Propinsi Bengkulu, di mana negara yang dituju untuk tahun 2017 adalah Negara Jerman, tepatnya di University of Cologne Jerman.

Salah satu narasumber menyatakan bahwa,

"Press ini sangat penting, terutama

di bidang kepustakawanan.

Dorongan ini akan memberi dampak yang positif bagi seseorang. Sebagai contoh jika ada seorang pustakawan yang punya potensi untuk menulis, maka ketika dia mendapat dukungan/ dorongan dari pimpinan dan lingkungan kerjanya, maka tentunya akan memberikan suatu dampak yang positif bukan hanya bagi dirinya tapi nama baik lembaga juga akan ikut menikmatinya" (Iswanto, R., wawancara, January 1, 2018).

Mengingat hal ini, Lebih lanjut Epstein (1999) dalam Rodin (2017) menyatakan bahwa, "Ide-ide kreatif tidak muncul begitu saja dari dalam otak kita, melainkan hasil dari interaksi kita dengan lingkungan". Oleh karena itu, lingkungan fisik dan sosial pun sebisa mungkin harus penuh dengan kreativitas pula. Perbanyaklah pergaulan dengan orangorang yang latar belakang, kepribadian, atau minatnya jauh berbeda.

Pada dasarnya, Rodin (2017) secara konkrit menggambarkan cara untuk membangun kreativitas inovatif pustakawan diantaranya, mengikuti perkembangan teknologi informasipustakawan harus memiliki keterampilan dalam menggunakan teknologi informasi, meminta izin kepada pimpinan untuk melanjutkan studi. Hal ini untuk mengimbangi perkembangan zaman dan 
tuntutan karir, mengikuti pelatihan kepustakawanan yang diselenggarakan oleh Perpustakaan Nasional dan lembaga lainnya untuk memperluas wawasan dan keterampilan serta kompetensi seorang pustakawan, melakukan studi banding atau belajar ke perpustakaan yang lebih maju baik di dalam maupun luar negeri. Pengalaman merupakan guru yang terbaik-melalui studi banding maka ada pelajaran dan pengalaman yang bisa diambil dan kemudian diterapkan di perpustakaan, peningkatan kompetensi berbahasa asing, minimalnya bahasa Inggris, dan mampu dalam penulisan karya tulis ilmiah dan penelitian pustakawan untuk menunjang referensi pustakawan untuk mengembangkan ideide kreatifnya.

Perpustakaan harus kreatif dan inovatif mengembangkan berbagai akitifitas yang menunjang kegiatan kepustakawanan. Kegiatan tersebut dapat dilakukan dengan mengadakan worskhop proses kreatif menulis, aktif menulis di media massa dan jurnal ilmiah, launching dan bedah buku, temu penerbit dan penulis buku. Selain itu, yang tidak kalah menarik adalah ketika pustakawan mampu mengadakan riset yang berbasis kepustakawanan. Hasil riset tersebut tentunya akan memberikan sumbangsih terhadap pengembangan perpustakaan dan kepustakawanan. Selanjutnya pemberian penghargaan dan hadiah kepada pemustaka yang aktif berkunjung atau pengunjung yang berpartisipasi besar terhadap citra perpustakaan supaya pemustaka tidak mudah bosan. Kegiatankegiatan seperti ini merupakan strategi pustakawan untuk membangun kreativitas inovatif dalam menciptakan hal yang baru, supaya pemustaka betah dan nyaman berkunjung ke perpustakaan.

\section{SIMPULAN}

Pustakawan perguruan tinggi dalam menghadapi era digital seperti sekarang ini, dituntut untuk selalu kreatif dan inovatif. Kreativitas dan inovasi yang dihasilkan berupa kinerja di bidang kepustakawanan dari para pustakawan perguruan tinggi merupakan suatu hal yang sangat diharapkan agar pustakawan perguruan tinggi dapat memainkan perannya dalam dunia akademik dan ilmiah. Oleh karena itu, kinerja yang sifatnya konstruktif dalam pengembangan kelembagaan secara umum, dan khususnya perpustakaan dan kepustakawanan itu sendiri, tentunya merupakan dua hal yang sangat diharapkan sebagai bentuk konkrit dari kinerja seorang pustakawan perguruan tinggi. Maka, pustakawan yang kreatif dan inovatif dalam pengembangan perpustakaan dapat diteliti kembali untuk melihat produk informasi di perpustakaan.

\section{DAFTAR PUSTAKA}

Alsop, J., \& Bordonaro, K. (2007). Multiple roles of academic librarians. Electronic Journal of Academic and Special Librarianship, 8(1), 1-10. Retrieved from

http:/ / southernlibrarianship.icaap.or g/content/v08n01/alsop_j01.htm

Andayani, U. (2016). Pustakawan akademik sebagai mitra riset di perguruan tinggi. Jurnal Al-Maktabah, 15(1), 29-40. Retrieved from http://journal.uinjkt.ac.id/index.php /almaktabah/article/view/4712/3243

Bara, A. K. (2012). Membangun kreativitas pustakawan di perpustakaan. Jurnal Iqra', 6(2), 40-51.

Cangara, Z. (2015). Reposisi pustakawan dalam era teknologi informasi. Jurnal JUPITER, 15(1), 9-12. Retrieved from http://journal.unhas.ac.id/index.php 
/jupiter/article/viewFile/23/21

Farhanah, N., Zulaikha, S. R. (2016). Hubungan antara kecerdasan emosi dengan kinerja pustakawan di perpustakaan. Jurnal Kajian Informasi $\mathcal{E}$ Perpustakaan, 4(2), 179-190. Retrieved from http://jurnal.unpad.ac.id/jkip/article /view/9971/4798

IAIN Bengkulu. (2018a). Al-Maktabah: Jurnal Kajian Ilmu dan Perpustakaan. Retrieved from http:/ / ejournal.iainbengkulu.ac.id/in dex.php/almaktabah

IAIN Bengkulu. (2018b). Perpustakaan IAIN Bengkulu. Retrieved from http:/ /library.iainbengkulu.ac.id/ind ex.php/2018/12/07/hello-world/

Menteri Pendayagunaan Aparatur Negara dan Reformasi Birokrasi Republik Indonesia. Peraturan Menteri Pendayagunaan Aparatur Negara \& Reformasi Birokrasi Republik Indonesia nomor 9 tahun 2014 tentang jabatan fungsional pustakawan dan angka kreditnya, Pub. L. No. 3 (2014). Indonesia: Menteri Pendayagunaan Aparatur Negara dan Reformasi Birokrasi Republik Indonesia. Retrieved from https:/ / www.perpusnas.go.id/lawdetail.php?lang=id\&id=170921121704 rQwKgUnEl7

Perpustakaan Sekolah Tinggi Agama Islam Negeri (STAIN) Curup. (2018). Jurnal Tik Ilmeu. Retrieved from http://journal.staincurup.ac.id/index .php/TI
Priyanto, I. F. (2017). Membangun mindset pustakawan: Resolusi ke-empat. In Seminar dan Workshop Perpustakaan $\mathcal{E}$ Pustakawan Inovatif Kreatif di Era Digital. Malang: Universitas Airlangga.

Rodin, R. (2014). Teknologi informasi dan fungsi kepustakawanan. Jurnal AlMaktabah, 13(1), 1-7. Retrieved from http://journal.uinjkt.ac.id/index.php /almaktabah/article/view/1569/1319

Rodin, R. (2017). Upaya pustakawan akademik menumbuhkan kreativitas dan inovasi di era digital (Studi di Perpustakaan Perguruan Tinggi Islam di Propinsi Bengkulu). Libraria: Jurnal Ilmu Perpustakaan Dan Informasi, 6(1), 73-95. Retrieved from https://fpptijateng.or.id/libraria/index.php/lib/i ssue/view / 1

Solso, L. R., Maclin, H. O., \& Maclin, K. M. (2008). Psikologi kognitif. Jakarta: Erlangga.

STAIN Curup Bengkulu. (2018). Perpustakaan. Retrieved from http:/ / devel.staincurup.ac.id/gtwebs ite $/$ index.php?option $=$ com_content $\&$ view $=$ article \&id $=208 \&$ Itemid $=744$

Sugiyono. (2010). Metode penelitian kuantitatif, kualitatif, dan $R \mathcal{E} D$ (Edisi 10). Bandung: Alfabeta.

Universitas Muhammadiyah Bengkulu (UMB). (2018). Perpustakaan Universitas Muhammadiyah Bengkulu. Retrieved from http://36.66.50.242:2016/pustakaumb /slim7/ 
